\title{
LAS DOS HIPÓTESIS DE OBJETO ILÍCITO CONTENIDAS EN EL ARTÍCULO 1465 DEL CÓDIGO CIVIL
}

Fabián Elorriaga De Bonis"

\section{RESUMEN}

El artículo 1465 del Código Civil contiene dos hipótesis diferentes de objeto ilícito: una, es el perdón anticipado del dolo futuro; otra, diferente es la que se configura cuando un finiquito contractual es obtenido con dolo. La regla según la cual el pacto de no pedir más o finiquito no valen en cuanto al dolo en él contenido, contiene un caso particular y específico de objeto ilícito, y no es una mera hipótesis de consentimiento contractual viciado, por lo mismo, la sanción para él es la nulidad absoluta del negocio y no la nulidad relativa.

Palabras claves: dolo, finiquito, condonación, objeto, ilícito

AbStRact

Both situations foreseen by the article 1465 of the Civil Code are hypothesis different, specific and qualified of illicit object. Both produce absolute nullity of the transaction in which they incide. The illicit object referred to in the first part of the article 1465 of the Civil Code is not reduced to an account rendered but it extends to any contractual release that contains the same vice. In order to understand the deceit to be condoned in a release or in an account's approval it is necessary that it has been expressly remitted and under the knowledge that it has taken place. If it wasn't thus, then it exists illicit object in its granting.

Key words: freud, approbation, release, subject matter, wrong

* Doctor en Derecho, Universidad de Navarra Profesor titular de Derecho Civil, Universidad Adolfo Ibáñez. Correo electrónico: felorria@uai.cl Artículo recibido el 21 de abril de 2009 y aceptado el 9 de junio de 2009. 


\section{LA CUESTIÓN}

Dispone el artículo 1465 del Código Civil:

"el pacto de no pedir más en razón de una cuenta aprobada, no vale en cuanto al dolo contenido en ella, si no se ha condonado expresamente. La condonación del dolo futuro no vale".

Esta norma, como se explicará de manera inequívoca, contiene dos hipótesis especialmente calificadas de objeto ilícito por el legislador y, por lo mismo, deben sancionarse con nulidad absoluta del negocio en que incidan, tal como lo ordena el artículo 1682 del Código Civil.

En cualquiera de estos dos casos, la nulidad absoluta puede ser alegada por todo el que tenga interés en ello, excepto por el que ha ejecutado el acto o celebrado el contrato, sabiendo o debiendo saber el vicio que lo invalidaba; no puede sanearse por la ratificación de las partes, ni por un período inferior a diez años. Además, en un plano puramente teórico, esta nulidad absoluta puede y debe ser declarada por el juez, aun sin petición de parte, cuando apareciere de manifiesto en el acto o contrato; y podría ser alegada por el ministerio público en el solo interés de la ley y $136 \quad$ la moral ${ }^{1}$.

\section{Antecedentes del artículo 1465 DEL Código CIVIL}

Las reglas del actual artículo 1465 del Código Civil conservan la fisonomía básica que se les dio desde el Proyecto de 1853, con pequeñas variantes.

En efecto, según el artículo 1644 del Proyecto de 1853 "el pacto de no pedir más en razón de una cuenta aprobada no vale en cuanto al dolo contenido en ella, si no se ha remitido señaladamente". Por otro lado, su artículo 1645 agregaba: "no vale la remisión del dolo futuro".

Como se advierte, a diferencia de lo que acontece en la actualidad, las dos reglas que ahora están juntas y fusionadas en el artículo 1465 del

${ }^{1}$ Se dice que esta posibilidad es sólo teórica, porque, como se comprende, es poco plausible que el dolo aparezca de manifiesto en el acto o contrato, ya que ello supondría que éste puede conocerse por el juez de la sola lectura o conocimiento del negocio, sin que tenga que relacionar para ello los diversos antecedentes probatorios existentes en el proceso; pero acreditado que sea el vicio de nulidad absoluta que no aparece de manifiesto en el negocio, el juez debe declararla. De la misma manera, hoy por hoy, al no existir el ministerio público en primera instancia, es, en los hechos, imposible que la nulidad pueda ser alegada por este organismo en la forma que indica el artículo 1683 del Código Civil. 
Código Civil, pero separadas por un punto seguido, originalmente estaban proyectadas como dos artículos distintos.

En el Proyecto inédito, la situación cambió, y las dos normas se unificaron en una sola. Esta norma, contenida en su artículo 1644, expresaba: "el pacto de no pedir más en razón de una cuenta aprobada, no vale en cuanto al dolo contenido en ella, si no se ha remitido señaladamente. La condonación del dolo futuro no vale". Se aprecia entonces que hasta ese momento el artículo todavía decía en su primera parte que el dolo, para ser perdonado, debía ser "remitido señaladamente", en lugar de "condonado expresamente", tal como hoy lo indica hoy el artículo 1465 del Código Civil.

Está redacción cambió en el Proyecto Definitivo, substituyéndose la expresión "remitido señaladamente", por la de "condonado expresamente", tal como dice hoy la norma.

En la forma en que fue concebido el precepto, puede afirmarse que no fue tomado de la legislación francesa sino que de la española. No existe en el Código Civil francés una norma equivalente o semejante a la que ahora se comenta ${ }^{2}$. En cambio, en una nota de Andrés Bello al mencionado artículo 1644 del Proyecto de 1853, se lee: "L. 30, Tít. 11, Part. 5". Otra nota al artículo 1645 de dicho Proyecto, decía: "L. 29, eod.". Naturalmente que se trata de referencias a las Siete Partidas de Alfonso X El Sabio.

La ley 30 del título 11 de la Partida 5, señalaba: "como la promision que es fecha en razon de cuenta que fuese dada de non gela demandar otra vez que non vale si engaño ouiere fecho en darla"; es decir, la promesa efectuada en razón de una cuenta de no demandar, no valía si el engaño hubiere sido hecho al rendir la cuenta.

Por su parte, la ley 29, que naturalmente antecede a la antes indicada, dispone: "la promision que ome fiziese a su mayordomo, o a su depensero que le non demandase el furto o el engaño que le fiziese q" non vale". Esto, por su parte, implicaba que la promesa que un hombre hiciere a su mayordomo, o a su despensero, en orden a que no lo demandaría por los hurtos o engaños que le hiciere, no vale.

Se aprecia entonces que las dos reglas que actualmente contiene el artículo 1465 del Código Civil provienen de la fusión de estos dos preceptos, que estan referidos a dos casos diferentes de invalidez. Si se le prometía a alguien que tenía la obligación de rendir una cuenta que no se le demandaría, tal pacto carecía de valor si había existido dolo, fraude o engaño al rendir la cuenta (actual primera parte del artículo 1465 del $C$ C). Por otro lado, si se le prometía a una persona que no se le demandaría por hurtos o engaños futuros, tal pacto también era inválido (actual segunda parte del artículo 1465 del $C C$ ).

\footnotetext{
${ }^{2}$ Véase infra, punto 6.
} 
Se dice que Andrés Bello, en este preciso caso, elaboró un principio o norma a partir de su expresión descriptiva en las leyes. Explica Alejandro Guzmán:

"en algunos casos las leyes vigentes ofrecían un cierto principio o norma, pero no manifestado como tal sino a través de una determinada descripción de situaciones de hecho; esta descripción obedecía en todo al principio, o sea, lo suponía, pero él no aparecía expresado (...) se intentaba extraer el principio insito en la descripción, que lo abrazaba plenamente. El ejemplo está dado por Part. 5.11.29: 'Condición, o prometimiento faziendo algund ome su mayordomo, o a su despensero, que non le demandasse engaño, nin furto que le fiziesse dende adelante; non valdría tal pleyto, ni tal prmission. E esto es, porque los tales pleytos podrían dar carrera a los omes, de fazer mal: e non deunen ser guardador. E esto desimos, que se deue entender desta guisa; que non vala el pleyto, on promisión, en los engaños, e en los furtos, que pudiesen fazer después del día en que fue fecha la promisión. Mas los otros que ouesessen ya fechos en ante la promission, bien podrían quitar por pleyto, o por postura, que faga aquel a quien los fizo, de nunca gelos demandar. E a lo que dize en esta ley de mayordomos, e de los despenseros, entiendese tambien de todos los otros omes, que tal pleyto, o promisión fiziessen entre si, sobre cualquier fecho que sea semejante destos'. Léase con detención esta ley y se convendrá en que lo expresado en ella no corresponde a más ni a menos que a lo expresado en la siguiente fórmula: La condonación del dolo futuro no vale, inscrita al final del art. 1465 del código. La nota al art. 1645, que contenía dicha fórmula en el Proyecto de 1853, indica que él se basó en la citada ley $29{ }^{\prime 3}$.

En cualquier caso, el principio de la invalidez en la condonación del dolo futuro también tiene precedentes romanos. De acuerdo con el Digesto

"llud nulla paction effici potest, ne dolos praesteur, quamvis si quis pacsiscatur, ne depositi Amat, vi ipsa id pactus vidaetur, ne de dolo agat; quod pactum proderit" ${ }^{4}$.

${ }^{3}$ Alejandro Guzmán Brito, Andrés Bello codificador. Historia de la fijación y codificación del derecho civil en Chile, Santiago, Ediciones de la Universidad de Chile, 1982, tomo 1, pp. 445 y 446.

${ }^{4}$ D. $2,14,27,3$. 
Ello implicaba que:

"no puede hacerse ningún pacto que no se preste dolo, aunque si alguno pactare no ejercitar la acción de depósito, se entienda pactado por la fuerza misma del pacto no ejercitar la del dolo; cuyo pacto aprovechará".

De la misma forma:

"pacta, quae turpen causam continent, non sunt obsrvanda; veluti si paciscar, ne furti agam vell iniriarum, si feceris; expedit enim timere furti vel iniuriarum poenam. Sed post admissa haec pacisci possumus ${ }^{2}$.

De modo que:

"los pactos que contienen causa torpe no deben observarse; por ejemplo, si yo pactare que no ejercitaré la acción de hurto ó de injurias, si los hubiese hecho; porque conviene temer la pena del hurto ó de las injurias. Pero después de cometidos éstos, podemos pactar"6.

De todo lo dicho, resulta que los antecedentes históricos de la formación de la norma, demuestran que en el actual artículo 1465 del Código Civil se fusionaron dos hipótesis diferentes de objeto ilícito, pero conservándose la sanción de invalidez para ambas, tal como se resolvía expresamente en las Siete Partidas?.

${ }^{5}$ D. $2,14,27,4$.

${ }^{6}$ Justiniano García del Corral (traductor y compilador), Cuerpo de Derecho Civil Romano, Barcelona, Editorial Lex Nova 1889, tomo 1: Instituta - Digesto, pp. 283 y 284.

${ }^{7}$ La fuente no resulta para nada extraña. Como explica Alejandro Guzmán las notas efectuadas por Andrés Bello al Proyecto de 1841-1845 y al Proyecto de 1853, permiten comprobar que la fuente que predominó "de manera incontrastable fue el código de las Siete Partidas, con la glosa de Gregorio López”. Esto resulta concordante con la propia opinión del codificador expuesta en 1839, según la cual nuestra legislación civil, sobre todo las Siete Partidas, encierra lo mejor de la jurisprudencia romana, cuyo permanente imperio sobre una tan ilustrada parte de Europa atestigua su excelencia. Agrega Alejandro Guzmán que el código francés, ocupó, sin dudas un lugar importante en la codificación chilena, pero sólo a nivel inspirador, ya que Andrés Bello rara vez copió alguna disposición de dicho cuerpo legal, pues, las más de las veces, acudió a la fuente inicial, esto es, a la opinión de Robert Joseph Pothier, o a sus comentaristas, por lo general a Claude-Etienne Delvincourt, superando siempre los modelos en el fondo y en estilo. Véase Alejandro GuZmán Brito, Código Civil chileno, Navarra, Aranzadi, 2006, pp. 44 a 46). 
A partir de estas hipótesis específicas, Andrés Bello extrajo dos reglas más generales: la primera es que el pacto de no pedir más en razón de una cuenta aprobada no vale en cuanto al dolo contenido en ella; y la segunda, es que tampoco vale la condonación del dolo futuro. Estos dos supuestos pasaron a ser casos específicos y calificados por la propia ley de objeto ilícito.

\section{FUNDAMENTOS DE LA PROHIBICIÓN DE CONDONAR EL DOLO FUTURO}

El fundamento de la prohibición del dolo futuro (regla segunda art. 1465 del $C C$ ) radica en la inmoralidad involucrada en la condonación anticipada de conductas ilícitas. Al legislador no le parece posible que puedan autorizarse de antemano actuaciones fraudulentas, dolosas o efectuadas de mala fe, pues ello repugna a la noción ética envuelta en el ordenamiento jurídico. Sería una suerte de acicate a que dichas conductas se ejecutaran, o la suposición de que ellas van a realizarse. Por otro lado, de aceptarse este expediente, se correría el riesgo cierto de que tal estipulación se convirtiera en una cláusula de estilo, impuesta en todo contrato por la parte con más poder de negociación, quedando sin aplicación las normas sobre la buena 140 fe contendidas particularmente en el Código Civil.

A este respecto escribe Luis Claro Solar: "es contraria a las buenas costumbres y al orden público la condonación anticipada del dolo que pueda una de las partes cometer en la ejecución de una convención"8.

También indica Eugenio Velasco que, tomando en cuenta que el dolo consiste en la intención positiva de inferir injuria a la persona o propiedad de otro, siendo, por lo tanto, un elemento reprobable, un factor ilícito e inmoral que la ley rechaza, es "fácil de comprender la razón de la ley al prohibir la remisión adelantada de un acto ilícito: esa condonación es también ilícita e inmoral".

Avelino León, por su parte, expresa:

"el legislador ha establecido este precepto por razones de moralidad, pues si uno de los contratantes o ambos pudieren tener perdonados de antemano actos dolosos que quisieran cometer, sería autorizar y fomentar la inmoralidad, suprimiéndose la norma fundamental de que

${ }^{8}$ Luis Claro Solar, Explicaciones de Derecho Civil chileno y comparado, reimpresión, Bogotá, Editorial Temis S.A., 1979, tomo 10, p. 289.

${ }^{9}$ Eugenio Velasco Letelier, El objeto ante la jurisprudencia, memoria, Santiago, Universidad de Chile, Facultad de Ciencias Jurídicas y Sociales, 1941, N²50. Disponible en www.cybertesis.cl. visitada el 10 de mayo de 2009. 
los contratos deben cumplirse de buena fe. Además, la condonación del dolo futuro podría pasar a ser una cláusula usual en los contratos" ${ }^{\prime 10}$.

Del mismo modo Arturo Alessandri Besa afirma:

"es evidente que el legislador, al establecer esta prohibición ha tenido en vista la protección de las buenas costumbres y de la moral, pues si se permitiera la condonación anticipada del dolo en los convenios, la mayoría de éstos contendrían tal cláusula, lo que daría carta blanca a la otra parte para ejecutar todos los actos dolosos que quisiera, pues la acción que el perjudicado tendría para reclamar de ese dolo, habría desaparecido. Con disposiciones semejantes en los contratos, especialmente en aquellos en que de alguna de las partes debe rendir cuentas, se fomentaría el dolo y la inmoralidad, por saberse los contratantes impunes de toda acción"11.

Asimismo, Carlos Ducci escribió:

"si esta disposición no existiera, todos los contratos contendrían como cláusula común una condonación del dolo futuro y éste dejaría de ser sancionado. Se destruiría, además, la presunción general de buena fe que impera en nuestro derecho privado" ${ }^{12}$.

De la misma forma señala Hernán Larraín que se prohíbe renunciar anticipadamente el dolo "pues si se permitiera hacerlo, tal condonación se estipularía en todo contrato y la ley implícitamente autorizaría a cometer actos ilícito. El precepto prohíbe condonar el dolo cuando es futuro, es decir, el que aún no se ha cometido"13.

Finalmente, Víctor Vial explica:

"la condonación del dolo futuro es reprobada por la ley porque supone que una de las partes de la convención en la que se estipula dicha condonación acepta anticipadamente que la otra lo haga víctima de engaños o que infrinja un contrato con la intención de dañar al acreedor, y porque implica una renuncia a perseguir

${ }^{10}$ Avelino LeÓn Hurtado, El objeto de los actos jurídicos, $2^{\mathrm{a}}$ ed., Santiago, Editorial Jurídica de Chile, 1983, p. 58.

${ }^{11}$ Arturo Alessandri Besa, La nulidad y la rescisión en el Derecho Civil chileno, Santiago, Imprenta Universitaria, 1949, tomo 1, p. 142.

${ }^{12}$ Carlos Ducci Claro, Derecho Civil. Parte general, $4^{\mathrm{a}}$ ed., Santiago, Editorial Jurídica de Chile, 1995, pp. 279 y 280.

${ }^{13}$ Hernán Larraín Ríos, Lecciones de Derecho Civil, Santiago, Editorial Jurídica de Chile, 1994, p. 310. 
la responsabilidad de la parte que actuó con dolo, lo que pugna contra principios esenciales del derecho como son la buena fe y la responsabilidad por los actos ilícitos" ${ }^{14}$.

\section{Fundamentos de la inValidez}

DE UN FINIQUITO RESPECTO DEL DOLO CONTENIDO EN ÉL

La justificación de la invalidez del pacto de no pedir más en razón del finiquito de una cuenta, en cuanto al dolo contenido en ella (regla primera del art. 1465 del $C C$ ), subyace en el principio general de la buena fe y en la imposibilidad de aprovecharse del propio dolo o de la propia culpa.

La señalada regla es del todo natural y comprensible. Se impide que quien ha rendido fraudulentamente una cuenta que fue aprobada por el destinatario de la rendición, en la ignorancia del engaño, se pueda excusar de la posterior demanda que éste interpusiere en su contra, invocando la aprobación del finiquito que presentó dolosamente. Eso sería tanto como aceptar que quien engaña a otro puede invocar su propio ardid para eludir los reclamos que se dirijan en contra de él.

Como se comprende, lo anterior no es posible; tal eventualidad es incompatible con el principio general de la buena fe que debe imperar a lo largo de todo el iter contractual, desde las negociaciones previas, pasando por la ejecución del contrato, hasta su conclusión ${ }^{15}$. Por eso señala Luis Claro Solar que como los contratos deben cumplirse de buena fe, se supone que la aprobación lisa y llana de una cuenta da a entender que quien presta la

"aprobación a la cuenta lo hace estimando verdaderas todas las partidas de esa cuenta. ... Al aprobar la cuenta no se ha pronunciado sobre un dolo que no conocía; y el pacto de no pedir más en razón de la cuenta aprobada no puede valer respecto del dolo contenido en la cuenta y que ignoraba el que la aprueba"16.

Por esa razón si el que aprobó el finiquito descubre después que ha sido engañado, puede demandar lo que se le deba o los perjuicios que se le han causado, sin que el que rindió la cuenta este habilitado para invocar en su beneficio el finiquito y el pacto de no pedir más, ya que en ello existe objeto ilícito.

${ }^{14}$ Víctor Vial del Río, Teoría general del acto jurídico, Santiago, Editorial Jurídica de Chile, 2006, p. 184.

${ }^{15}$ Cfr. Jorge López Santa María, Los contratos. Parte general, $4^{\mathrm{a}}$ ed., Santiago, Editorial Juridica de Chile, 2005, p. 405.

${ }^{16}$ Claro Solar (n. 8), p. 289. 
Es contrario al principio de buena fe contractual que una de las partes de un negocio jurídico quiera aprovecharse de su propio fraude. La vieja máxima nemo auditur propriam torpitudinem allegans, está ampliamente recogida no sólo en la primera parte del artículo 1465 del Código Civil sino que en muchas otras disposiciones que niegan valor a cualquier pacto o acuerdo que se funde en el aprovechamiento del propio dolo o de la propia culpa.

Así, por ejemplo, no puede repetirse lo que se haya dado o pagado por un objeto o causa ilícita a sabiendas (art. 1468 del $C C$ ); si una persona que está obligada bajo condición se vale de medios ilícitos para que ella no pueda cumplirse, la condición se tendrá por cumplida (art. 1481.2 del CC); las cláusulas ambiguas de un contrato que hayan sido extendidas o dictadas por una de las partes, sea acreedora o deudora, se interpretarán en contra de ella (art. $1566.2 \mathrm{del}(C)$ ); si de parte del incapaz ha habido dolo para inducir al acto o contrato, ni él ni sus herederos o cesionarios podrán alegar la nulidad (art. 1685 del $C C$ ); es nulo todo pacto en que se exime al vendedor del saneamiento de evicción, siempre que en ese pacto haya habido mala fe de parte suya (art. 1842 del $C$ C); si se ha estipulado que el vendedor no estuviese obligado al saneamiento por los vicios ocultos de la cosa, estará, sin embargo, obligado a sanear aquellos de que tuvo conocimiento y de que no dio noticia al comprador (art. 1859 del $C C$ ); y, puede alegar la nulidad absoluta todo el que tenga interés en ello, excepto el que ha celebrado el acto o ejecutado el contrato sabiendo o debiendo saber el vicio que lo invalidaba (art. 1683 del CC).

Fuera del Código Civil, también impera la regla de que nadie puede aprovecharse de su propia culpa o su propio dolo. Así, la separación judicial solamente puede ser demandada por el cónyuge que no haya dado lugar a la causal de separación (art. 26.3 de la LMC); la nulidad del matrimonio por causa de error o fuerza solamente puede ser impetrada por el presunto cónyuge que padeció el error o la fuerza (art. 46 letra b de la LMC) y el divorcio por causa imputable a uno de los cónyuges sólo puede ser demandado por aquél que no hubiera dado lugar a los hechos que configuran la causal (art. 56.2 de la LMC).

Como síntesis, y en palabras de Ramón Domínguez:

“por razones de moral, el derecho no puede dar protección jurídica integral a aquel que se ha puesto por su propia actividad, dolosa o culpable o ilícita en términos más generales, en situación de ser perjudicado por esa misma actividad" ${ }^{17}$.

${ }^{17}$ Ramón Domínguez Águila, Teoría general del negocio jurídico, Santiago, Editorial Jurídica de Chile, 1977, p. 226. 
En consecuencia, la buena fe contractual y el principio del nemo auditur impiden que quien dolosamente ha rendido una cuenta que ha sido aprobada gracias a estas maniobras, pueda en el futuro excepcionarse de la demanda deducida por el perjudicado en su contra, sobre la base del finiquito que él mismo obtuvo gracias a su propio dolo. Sencillamente, el pacto de no pedir más otorgado en estas condiciones, no vale.

\section{Dos Casos indiscutidos De Objeto ilícito}

Como es ampliamente sabido, el Código Civil chileno no dice lo que es el objeto ilícito, sino que, por una parte, señala que el negocio jurídico debe tener un objeto lícito (art. $1445 \mathrm{del} C C$ ), y, por otra, indica ciertos casos de objeto ilícito (arts. 1462 a $1466 \mathrm{del} C C$ ).

Así, indiscutidamente, existe un objeto ilícito en todo lo que contraviene el Derecho Público chileno (art. 1462 del CC); en los pactos que versan sobre el derecho a suceder a una persona viva (art. 1463 del CC); en la enajenación de las cosas que no están en el comercio, de los derechos o privilegios personalísimos, de las cosas embargadas por decreto judicial y de las cosas cuya propiedad se litiga (art. $1464 \mathrm{del} C C$ ); en la condonación del dolo futuro y en el pacto de no pedir más en razón de una cuenta aprobada que contenga dolo (art. 1465 del $C C$ ); y, en general, en todo contrato prohibido por la ley, como las deudas contraídas en juegos al azar, en la venta de libros de circulación prohibida, en la de estatuas obscenas y en la de impresos abusivos de la libertad de prensa (art. 1466 del $C$ C).

Todas éstas son hipótesis específicamente consideradas de objeto ilícito por parte del legislador. Se trata de casos calificados de objeto ilícito; de situaciones en las que, más allá de las disquisiciones doctrinarias o legales que puedan hacerse, el objeto ilícito ha sido definido con entera claridad por parte de la ley, por lo que son eventos en los que indiscutidamente el objeto del acto no es lícito. En palabras de Luis Claro Solar, los casos indicados en los artículos 1462 a 1466, "son casos calificados de objeto ilícito, sancionados por la ley con la nulidad del acto en que inciden" ${ }^{18}$.

Esto significa que todos los supuestos señalados por el Código Civil como de objeto ilícito, deben ser tenidos como tales, a pesar de que puedan no encajar exactamente con el concepto doctrinal que quiera elaborarse de objeto ilícito. Se trata de eventos indiscutibles de ilicitud del objeto, porque el legislador los ha previsto especialmente como tales, y no cabe impugnarlos bajo el argumento de que ellos no se encuadran bien con lo que en teoría debiese ser la noción de objeto ilícito, o bajo la idea de que ellos debieren sancionarse

${ }^{18}$ Domínguez Águila (n. 17), p. 303. 
de una manera diferente de la nulidad absoluta ordenada expresamente por el artículo 1682 del Código Civil para este tipo de infracciones.

El Código Civil zanjó así las discusiones a que da lugar entre nosotros el concepto de objeto ilícito, pues el señalamiento de casos específicos en que el objeto no es lícito, elimina cualquier controversia al respecto.

En este preciso sentido señalan Arturo Alessandri R., Manuel Somarriva U. y Antonio Vodanovic H. que, con independencia del concepto de objeto ilícito, "señalando el legislador los casos de objeto ilícito, hay que tenerlos como tales aunque no respondan siempre a la noción doctrinariamente correcta o a una idea general única"19.

La doctrina nacional se uniforma en que existe una especial calificación de objeto ilícito por parte del legislador en cada una de las situaciones previstas entre los artículos 1462 y 1466 del Código Civil, y que, en virtud de esta calificación legal expresa, sólo cabe sancionar estos actos con la nulidad absoluta por ilicitud de su objeto. Por eso que Ramón Domínguez afirma que el problema queda referido no a la:

"definición de lo que debe entenderse por ilicitud, sino a la precisión de las situaciones en que el orden positivo excluye un interés de la negociación privada, idea que parece, desde un punto de vista técnico, más adecuada y precisa y es la que, respecto de esta materia, parece seguir nuestro Código, que señala justamente las situaciones en que existe objeto ilícito" 20 .

Esta noción de especialidad de los casos de objeto ilícito por sobre cualquier otra consideración de orden doctrinario, como se ha dicho, está presente en las palabras de prácticamente todos los doctrinadores nacionales que se han ocupado del punto. Así Avelino León escribe: “el Código, después de indicar el contenido del objeto en los arts. 1460 y 1461, señala en los cinco artículos siguientes casos específicos de objeto ilícito"; de hecho el capítulo $\mathrm{v}$ de su libro dedicado especialmente al estudio del objeto de los actos jurídicos, se titula "Casos de objeto ilícito reglamentados especialmente" Exactamente lo mismo afirma Arturo Alessandri Bessa, quien se refiere a estos supuestos como "casos especiales de objeto ilícito que contempla el Código Civil chileno", y en los que el Código adopta el criterio general en materia de "ilicitud del objeto" 22 . También Carlos Ducci señala:

${ }^{19}$ Arturo Alessandri Rodríguez, Manuel Somarriva Undurraga y Antonio Vodanovic Haclicka, Tratado de Derecho Civil, Santiago, Editorial Jurídica de Chile, 1998, tomo II, p. 259 (Lo destacado en el texto es nuestro).

${ }^{20}$ Domínguez (n. 16), p. 146 (Lo destacado es nuestro).

${ }^{21}$ LEÓn (n. 10), p. 45 (Lo destacado en el texto es nuestro).

22 Alessandri Besa (n. 11), p. 123. 


\begin{abstract}
“el sistema del Código es perfectamente lógico; la ley sanciona el objeto ilícito y éste, para su licitud, debe cumplir los requisitos que la ley señala el artículo 1461 y no consistir en ninguno de los pactos en que los artículos siguientes señalan expresamente que hay objeto ilícito" ${ }^{23}$.
\end{abstract}

De la misma forma Hernán Larraín explica que:

"nuestro Código, después de dar a entender que hay objeto ilícito, en general, en los casos señalados, se encarga de mencionar una serie de casos particulares en que hay objeto ilícito" ${ }^{24}$.

También Rodrigo Barcia se refiere a cada uno de los casos tratados en el Código Civil como "causales específicas de objeto ilícito"25. Finalmente, sentencia Víctor Vial: "si bien el Código, como hemos dicho, no define el objeto ilícito, señala algunos casos en que se presenta con especial relevancia la ilicitud del objeto" ${ }^{26}$.

En consecuencia, es conclusión uniforme en la doctrina nacional que se ha ocupado del tópico del objeto de los negocios jurídicos, que en todos los casos señalados por el Código Civil entre sus artículos 1462 y 1466, contienen un objeto ilícito, y, por lo mismo, en los términos del artículo 1682 del mismo 146 Código, la nulidad producida por un objeto ilícito es una nulidad absoluta.

Lo anterior es cierto aun cuando el artículo 1465 del Código Civilno diga expresamente que las situaciones por él descritas son de objeto ilícito. Esto porque el artículo en cuestión está ubicado precisamente entre los casos de objeto ilícito que menciona dicho cuerpo legal. Por otro lado, si bien la norma no usa las palabras "objeto ilícito", sí utiliza en dos ocasiones la expresión "no vale", que es una de las muchas formas que el Código tiene de expresar una prohibición asociada a la ilicitud del objeto ${ }^{27}$. Como indica Eugenio Velasco, el artículo 1465, sin nombrar la ilicitud del objeto, señala casos en que ella existe ${ }^{28}$. Por si alguna duda aún cupiese, ella resulta completamente aclarada por la redacción del artículo siguiente, es decir, el 1466, que comienza diciendo: "hay asimismo objeto ilícito..."; la expresión 'asimismo', hace definitiva claridad en orden a que el caso del artículo anterior también es de objeto ilícito. Por demás, así se ha fallado ${ }^{29}$.

${ }^{23}$ Ducci (n. 12), p. 277 (Lo destacado en el texto es nuestro).

${ }^{24}$ LARRAín (n. 13), p. 308 (Lo destacado en el texto es nuestro).

${ }^{25}$ Rodrigo Barcia Lehmann, Lecciones de Derecho Civil chileno, Santiago, Editorial, Jurídica de Chile, 2007, tomo i: Del acto jurídico, p. 88.

${ }^{26}$ ViAl del Río (n. 14), p. 165 (Lo destacado en el texto es nuestro).

${ }^{27}$ Cfr. Ducci (n. 12), p. 280.

${ }^{28}$ Velasco (n. 9), No 81.

${ }^{29}$ Revista de Derecho y Jurisprudencia vol. 89, No 1, Santiago, 1992, p. 24. 
Por lo tanto, no es dudoso en nuestro Derecho que cualquiera de los actos a que se refiere el artículo 1465 del Código Civil tiene un objeto ilícito. De ahí que, por esta causa, no vale el finiquito de una cuenta respecto del dolo contenido en ella, y tampoco la cláusula por la que se condona el dolo futuro.

6. LA REGLA PRIMERA DEL ARTÍCULO

ES UN CASO DE OBJETO ILÍCITO Y NO UN MERO VICIO

DEL CONSENTIMIENTO CONTRACTUAL

En el sentido antes descrito, la regla de invalidez absoluta que establece formal y expresamente el artículo 1465 del Código Civil, en relación con el artículo 1682 del mismo Código, se configura como una excepción a la nulidad relativa con que se castigan los actos viciados con dolo, pues en este caso se enfrenta una hipótesis de objeto ilícito que produce la nulidad absoluta. Según lo prevenido en los artículos 1451 y 1458 del Código Civil, el dolo es un vicio del consentimiento que impide que una persona se obligue válidamente con otra por un acto o declaración de voluntad (art. $1445 \mathrm{~N}^{\circ}$ 2 del $C$ C). En consonancia con ello, es nulo todo acto o contrato al que falta alguno de los requisitos que la ley prescribe para el valor del mismo acto o contrato, según su especie y la calidad o estado de las partes (art. 1681.1 del $C$ C). Como los vicios del consentimiento no están sancionados expresamente con nulidad absoluta, los actos en los que ellos incidan, se sancionan con nulidad relativa, ya que cualquier otra clase de vicio que no sea el objeto o la causa ilícita, o la omisión de un requisito de validez exigido en consideración a la naturaleza del acto, da derecho a la nulidad relativa del acto (art. 1682.3 del $C C$ ).

Sin embargo, en el preciso caso de la primera parte del artículo 1465 del Código Civil, el fraude no produce la nulidad relativa del pacto de no pedir más en razón de la cuenta aprobada, sino que su nulidad absoluta. El legislador ha sido mucho más drástico con el dolo o fraude cometido en un finiquito que con el que puede existir en otro tipo de negocios. Como se dijo, la uniformidad de la doctrina nacional entiende, con razón, que en la especie se está en presencia de un caso calificado o específico de objeto ilícito, lo que importa una tipificación legal que no puede controvertirse sin infringir el tenor literal de la norma. El camino seguido por el Código Civil de describir hipótesis concretas de objeto ilícito, tiene el mérito de evitar la discusión en orden a si un determinado objeto contractual es o no lícito, cerrando así la ley todo espacio para ello. Por eso, ninguno de los autores nacionales que se refieren a este extremo ha puesto en duda que en este caso se enfrenta un caso de objeto ilícito sancionado con nulidad absoluta. 
Podría pensarse que para lograr armonía entre la sanción general para los vicios del consentimiento (nulidad relativa) y la sanción para el dolo en un pacto de no pedir más en razón de una cuenta aprobada (nulidad absoluta), todas las hipótesis de dolo debieran sancionarse con nulidad relativa. Sin embargo, además de la dudosa conveniencia de aquello, tal planteamiento es de lege ferenda, pero no de lege data. El texto del artículo 1465 del Código Civil es explícito, y conforme a la primera y principal regla de interpretación, cuando el sentido de la ley es claro, no se desatenderá su tenor literal, a pretexto de consultar su espíritu (art. 19 del $C C$ ). En este escenario tratar de aplicar la sanción de nulidad relativa a la hipótesis prevista en la primera parte del artículo 1465 del Código Civil, no sería más que pasar por sobre el texto de la ley.

Además, no puede obviarse algo elemental. El inciso final del artículo 1682 del Código Civil señala que cualquier otra clase de vicio que no sea el objeto o la causa ilícita, o la omisión de un requisito de validez exigido en consideración a la naturaleza del acto, da derecho a la nulidad relativa del acto. En otros términos, la nulidad relativa se aplicará sólo cuando no se esté en presencia de un objeto ilícito tipificado en la ley. Pues bien, acontece que la primera parte del artículo 1465 del Código Civil describe una específica hipótesis de objeto ilícito. Por lo tanto, habiéndose indicado por la ley que la conducta descrita en la primera parte del artículo 1465 es un supuesto de objeto ilícito, no cabe aplicar como sanción la nulidad relativa, sino que, necesariamente, la nulidad absoluta prevista en el inciso primero del artículo 1682 del Código Civil para este tipo de vicio.

Por otro lado, si no fuere como se indica, ocurriría que la primera regla del artículo 1465 del Código Civil estaría demás; se trataría de una norma completamente innecesaria o una evidente repetición de lo dispuesto para el dolo como vicio de la voluntad. Para anular un finiquito contractual obtenido con dolo bastaría con recurrir a las normas generales sobre los vicios del consentimiento (arts. 1451, 1458 y 1682 del CC); sobrando la primera parte del artículo 1465. ¿Qué sentido tendría decir, dentro de los casos de objeto ilícito, que un acto puede rescindirse si ha sido otorgado con dolo? Obviamente que ninguno, pues ésa es la regla general. Si así fuera, la primera parte del artículo 1465 del Código Civil no se aplicaría nunca, sería una torpe repetición de la regla general, redundancia poco frecuente en la obra del legislador civil; más aún si se tiene en cuenta que el precepto está ubicado precisamente entre los casos de objeto ilícito que enumera el Código Civil. Es evidente que esto, además de contrariar el claro texto de la ley, carece de todo sentido. No puede privilegiarse la lectura o la interpretación de una norma de manera que ésta quede sin aplicación práctica. Entre la lectura que le da sentido a un precepto legal y la que no le da ninguno, debe ser preferida la que le da sentido y aplicación. 
Según Avelino León, el artículo 1465 es una "disposición prohibitiva y, en consecuencia, su sanción es la nulidad absoluta" 30 . Esta afirmación se basa en que, de conformidad con el artículo 10 del Código Civil, los actos que la ley prohíbe son nulos y de ningún valor, salvo en cuanto se designe expresamente otro efecto que el de nulidad para el caso de contravención. En concordancia con ello, y según lo prevenido en el artículo 1466 del mismo Código, hay objeto ilícito en todo contrato prohibido por las leyes. Finalmente, según el artículo 1682, el objeto ilícito se sanciona con la nulidad absoluta del negocio en cuestión.

La diferencia de tratamiento que el Código Civil dedica al dolo vicio del consentimiento y el dolo objeto ilícito, se explica por la decisión de incluir dentro del catálogo de hipótesis de objeto ilícito, aquella que desde hace siglos estaba presente en las Siete Partidas, consistente en que la promesa de no pedir más en razón de una cuenta aprobada carece de valor si la rendición de ella ha sido dolosa, que no existía en la legislación francesa ${ }^{31}$.

En efecto, los artículos 1451 y 1458 del Código Civil, relativos al dolo vicio del consentimiento, sí tienen su claro correlato en los artículos 1109 y 1116 del Código Civil francés. Según el primero, "no habrá consentimiento válido, si el consentimiento hubiera sido dado por error, o si hubiera sido arrancado con violencia u obtenido mediante dolo"; de acuerdo con el segundo, "el dolo será causa de nulidad del contrato cuando las maniobras practicadas por una de las partes sean tales, que resulte evidente que, sin esas maniobras, la otra parte no hubiera contratado". "El dolo no se presume y deberá ser probado". La similitud con nuestros artículos es más que evidente.

Sin embargo, el artículo 1465 del Código Civil, como se dijo, no fue tomado del Código Civil francés, sino que de las Siete Partidas. El Code no contiene un catálogo de hipótesis de objeto ilícito al estilo del Código chileno ${ }^{32}$, y sus artículos 1126 y 1130 se limitan a mencionar los requisitos que debe reunir el objeto de los actos jurídicos ${ }^{33}$. Entonces es inconcuso que mediante

${ }^{30}$ LEÓN (n. 10), p. 58.

${ }^{31}$ Véase supra, punto 2.

${ }^{32}$ Explica Avelino León: "en el Derecho francés, Pothier, y más tarde el Código Civil, no mencionan la licitud del objeto entre las condiciones necesarias para la validez de la obligación estableciéndose la salvaguarda de la moral y del orden público al regular la causa (arts. 1131 y 1133)", véase (n. 10), p. 42.

${ }^{33}$ El notable trabajo de Miguel Elizalde sobre concordancias entre los códigos civiles de Chile y Francia, no recoge vinculaciones entre nuestro artículo 1465 y alguna disposición francesa. Eso a diferencia de los artículos 1451 y 1458, sobre vicios del consentimiento y dolo, que sí tienen su referente en los artículos 1109, 1116 y 1118 del código francés. También alguna concordancia existe entre nuestro artículo 1463 y el artículo 1130 del código galo, que le niegan valor a los pactos sobre sucesiones futuras; y entre el artículo $1464 \mathrm{~N}^{\mathrm{o}} 1$ del Código chileno y el artículo 1128 del código francés, que impiden contratar sobre cosas que 
la incorporación de hipótesis legales de objeto ilícito se quiso evitar las dudas, incertidumbres o discusiones que podrían originarse en torno a si un determinado contrato contenía o no un objeto ilícito. De no existir claridad a este respecto, la resolución de cuándo hay objeto ilícito habría quedado entregada exclusivamente a la decisión siempre subjetiva del tribunal, con todas las dificultades que ello trae aparejadas. Por eso se optó por un remedio más eficiente: establecer una serie de casos en que el objeto es incuestionablemente ilícito. Entre ellos Andrés Bello tomó el contemplado en la ley 30 del título 11 de la Quinta Partida, que, como se indicó, disponía que la promesa de no demandar efectuada en razón de la aprobación de una cuenta, no valía si el engaño hubiere sido hecho al rendir la cuenta, y lo introdujo en la primera parte de nuestro actual artículo 1465 del Código Civil. De esta manera se creó un particular supuesto de objeto ilícito y no un mero caso de vicio del consentimiento contractual ${ }^{34}$.

En consecuencia, parece bastante evidente que no es posible afirmar que siendo el dolo el vicio involucrado en la regla de la primera parte del artículo 1465, debiera sancionarse el acto con nulidad relativa, pues, lo que en este caso ocurre es que el vicio del acto no es el dolo sino que el objeto ilícito. Esto es así porque, como indica Eugenio Velasco, la norma legisla "sobre el objeto de la obligación, pese al uso de la palabra pacto, en este caso sinónimo 150 de convención" 35 . Se da así la particular situación en que el dolo en que se incurre al rendir una cuenta provoca la ilicitud del pacto de no pedir más en razón de esa cuenta; se hace ilícito el objeto mismo del finiquito.

Por otro lado, existen buenas razones para que el legislador sea mucho más severo con el dolo contenido en un finiquito contractual (objeto ilícito) que con el que incide en el resto de los negocios jurídicos (vicio del consentimiento).

El que concurre en el finiquito contractual resulta más reprochable que el que se utiliza para que otro manifieste su voluntad contractual, pues en

no están en el comercio. No existen concordancias, además, con los casos de objeto ilícito contemplados en los artículos 1462, 1464 números 2, 3 y 4 y 1466 de código de Chile, véase Miguel Elizalde, Concordancias de los artículos del Código Civil Chileno entre sí con los artículos del Código Francés, Santiago, Imprenta de La Libertad, 1871, pp. 336 a 340.

"Los proyectos de Código Civil publicados en El Araucano de 1842 a 1345 y de 1846 a 1847 , respectivamente, y el proyecto de 1853, no se referían en parte alguna al objeto ilícito, sino que hablaban -al igual que el Código Francés- únicamente del objeto, aludiendo en cambio, a la causa ilícita "; fue el llamado Proyecto Inédito, el que varió la cuestión y exigió, como en el Código vigente, la licitud del objeto". Velasco (n. 9), No 71.

En el mismo sentido pueden consultarse las fuentes y concordancias citadas en el Repertorio de legislación y jurisprudencia chilenas. Código Civil y leyes complementarias, Santiago, Editorial Jurídica de Chile, 1997, tomo IV, pp. 89 a 114.

${ }^{34}$ Véase supra, punto 2.

${ }^{35}$ Velasco (n. 9), $\mathrm{N}^{\mathrm{O}} 18$. 
el primero se actúa mal dos veces en lugar de una sola. Primero, se procede incorrectamente incumpliendo la obligación y, luego, se vuelve a hacerlo al tratar amnistiar el propio incumplimiento mediante un engañoso finiquito. Mediante el dolo en la rendición de la cuenta, el fraudulento persigue su impunidad; busca asegurarse, por el engaño, que quedarán extintas sus incumplidas obligaciones sin que reproche alguno pueda hacerle su contraparte. La aprobación de la cuenta por el destinatario de ella, se transforma en una suerte de salvaguarda construida precisamente por el que ha actuado mal para que nada se le demande; el finiquito es el injusto escudo del autor de la cuenta torcida o del incumplimiento encubierto. La aprobación de la cuenta fraudulenta se transforma, de esta manera, en la coartada perfecta del que incumple; pues ha engañado o defraudado a su contraparte, pero mediante el finiquito pretende, además, construir un muro que lo ponga a salvo de las acciones del perjudicado. Se concreta así el aprovechamiento del propio dolo, que es el que la ley repudia ${ }^{36}$. Como se ha dicho: en estos casos existen dos actitudes alejadas de derecho: una es la de incumplir con la obligación y la otra es la de pretender sanearlo todo mediante el finiquito doloso. Así, por ejemplo, actúa mal el mandatario que se apropia de fondos que le han sido proporcionados para la ejecución del cargo; pero vuelve a actuar mal cuando rinde una cuenta fraudulenta que oculta su apropiación al mandante, con el propósito de que el finiquito que resulte de ello, impida al mandante la persecución de la obligación incumplida. Este doble comportamiento negativo demuestra que el reproche legal más drástico es justificado, y no se traduce en más que entender que el muro que ha pretendido construir quien ha obtenido el finiquito con dolo, carece de valor.

A mayor abundamiento, no es lo mismo el dolo contenido en la celebración de un contrato que el usado para obtener una desvinculación contractual mediante el expediente del finiquito. Quien da comienzo a una relación contractual diferida en el tiempo, tiene más posibilidades para percatarse de si ha sido engañado y del eventual daño que ello le causa. El desarrollo del contrato a través del cumplimiento de las obligaciones da espacio a la víctima del fraude para entender la naturaleza, tipo y entidad del engaño. Están dados el tiempo y las condiciones para desentrañar la maquinación que lo afecta y para evaluar qué tanto habría variado su posición contractual de no mediar el fraude. Bien podría descubrir que, a pesar del dolo, de todas formas habría contratado, aunque en condiciones distintas, caso en que no se producirá la rescisión del negocio sino que el perjudicado sólo tendrá derecho a la indemnización del daño que se le ha causado (art. 1458 del CC). Sin embargo, nada de esto ocurre cuando se

${ }^{36}$ Véase supra, punto 4. 
pone término a una relación contractual por medio de una fraudulenta rendición de cuenta destinada a finiquitar la relación. En este caso, el vínculo contractual no comienza sino que termina, quedando las partes liberadas, pues, como se dice más adelante, con el finiquito se pretende, precisamente, la extinción de la deuda. Al quedar desvinculados los contratantes, pocas posibilidades tiene el defraudado de percatarse del engaño; el contrato ya no está en ejecución, los partícipes pueden no estar en contacto y puede tardar mucho tiempo conocerse la existencia y alcance del fraude. Así las cosas, en los hechos, puede resultar harto más grave ser engañado al momento de finiquitar una relación contractual que al momento de contraerla.

Finalmente, abona todo lo dicho la circunstancia de que las rendiciones de cuenta o finiquitos implican una liberación para las partes. El mérito liberador del finiquito contractual hace que el dolo contenido en él sea mucho más peligroso y repudiable que el que pueda incurrirse para inducir a otro a contratar. Cuando incide en el nacimiento del contrato o, aun, en su ejecución, ahí están los mecanismos legales de impugnación del contrato, de oposición al cumplimiento o de reclamación de perjuicios; el perjudicado podrá incluso excepcionarse de cumplir su obligación alegando la nulidad del contrato o el incumplimiento malicioso de la contraparte. En cambio, cuando se usa para conseguir un finiquito, la relación contractual fenece, queda ajustada, y las partes sin nada que reclamar la una de la otra. El finiquito llevará envuelta la renuncia a todo tipo de impugnaciones, responsabilidades, acciones y recursos. De esta forma, la parte defraudada queda desarmada frente al que lo ha engañado. Nada puede exigirle, nada puede reclamarle, ninguna acción puede entablarle, todas están extintas por el finiquito o la aprobación de la cuenta. Entonces su camino legal es la impugnación del finiquito por la ilicitud de su objeto.

\section{Amplitud del ARTículo 1465 \\ DEL Código CIVIL}

La cuestión de su amplitud se relaciona con el tipo de conductas ilícitas que a él se refiere.

Se ha sostenido que no estaría bien redactado, ya que primero enuncia un caso concreto de objeto ilícito y luego la regla general a la que el caso se refiere. En este sentido, se dice, la redacción debería tener el orden lógico inverso, es decir, primero debería indicarse la regla general, esto es, que la condonación del dolo futuro no vale, y luego agregar la conducta específica ilícita, esto es, que la aprobación de una cuenta no vale respecto de dolo contenida en ella, salvo que esta remisión del dolo se haga expresamente. 
Ésa fue en su momento la opinión de Eugenio Velasco, quien escribió en su momento:

"la simple lectura de este precepto deja en claro que su redacción es defectuosa por haber alterado el orden lógico: la frase final del artículo es la que sienta la regla general, y el resto no es sino un caso de aplicación de ese principio, aun cuando la forma que el legislador le dio lo haga aparecer como la parte principal" ${ }^{37}$.

Sin embargo, si se tiene en cuenta el examen de los textos de los que se valió Andrés Bello para la redacción del artículo, resulta que se trata de dos situaciones distintas de objeto ilícito, que, por un común denominador, fueron agrupadas en una sola norma ${ }^{38}$. En ambos casos está presente la idea de la condonación del dolo, en un caso lo condonado es el dolo presente o pasado y en el otro el dolo futuro. Por eso para Avelino León "si se considera con atención este artículo, queda claro que se refiere a dos casos distintos: la condonación del dolo contenido en una cuenta, o sea, dolo presente o pasado, y la condonación del dolo futuro"39.

De esta forma, un caso de objeto ilícito es el pacto de no pedir más en razón de una cuenta rendida con dolo, y otro caso diferente es el contenido en el perdón anticipado del dolo futuro. Lo que ocurre es que el primer caso el dolo está contenido específicamente en la aprobación de una cuenta, en términos que la parte que extiende el finiquito ignora el dolo, y la aprueba en desconocimiento del fraude del que ha sido objeto. En tanto que, en el segundo caso, aún no tiene lugar, es un hecho futuro, y se le perdona de antemano. Sin embargo, por expresa disposición legal, ambas conductas envuelven supuestos de objeto ilícito, sancionables con la nulidad absoluta de la estipulación, sea aquélla por la que se aprueba el finiquito de la cuenta, sea en la que se perdona anticipadamente el futuro dolo.

Por lo mismo, aun cuando el artículo comienza refiriéndose al pacto de no pedir más en razón de una cuenta que ya ha sido aprobada por el destinatario de la rendición, es evidente que en ella se contiene una idea mucho más general relativa a la condonación del dolo. El precepto transcrito, como escribe Victor Vial:

“contiene una norma de carácter general en lo relativo a la condonación del dolo futuro, esto es la aceptación y perdón de la conducta dolosa que pudiera tener una de las partes en el porvenir, sea que

\footnotetext{
${ }^{37}$ Velasco (n. 9), N²50.

${ }^{38}$ Véase supra, punto 2.

${ }^{39}$ Ibid.
} 
dicha condonación constituya una cláusula de la convención en que el acreedor se compromete con el deudor a no pedir más en razón de una cuenta que ha sido aprobada, o que constituya una cláusula de cualquiera convención o contrato" ${ }^{40}$.

La frase "el pacto de no pedir más en razón de una cuenta aprobada" que usa la primera parte del artículo 1465 del Código Civil, es equivalente a un finiquito contractual. Como señala León Brailovsky mediante la cláusula de finiquito se pone término a una relación contractual ajustándose las cuentas que puedan existir entre las partes, quedando el deudor liberado de las obligaciones que le imponía el contrato. La expresión 'finiquito' proviene de la expresión latina finire, que significa 'acabar' o 'extinguir', pues con el finiquito efectivamente se acaba o extingue una deuda ${ }^{41}$. Como señalan Ricardo Villa-Real y Miguel Ángel del Arco, el finiquito “es un remate de cuentas o certificación que se da para constancia de que están ajustadas y satisfecho" 42 , así el finiquito no es más que el remate de una cuenta pendiente. Por su parte, indica Rodrigo Quijada que el finiquito es "un documento en el que consta el término de una operación mercantil", y, más genéricamente, es el "documento en el que consta la extinción de una obligación" 43 .

154 Por eso que al referirse a la primera parte del artículo 1465 del Código Civil, es frecuente que nuestros autores identifiquen el pacto de no pedir más en razón de una cuenta aprobada con un finiquito contractual, ya que por medio de éste, las partes acuerdan quedar recíprocamente liberadas, con sus cuentas aprobadas y sin reclamos que hacerse ${ }^{44}$. También por eso que, tal como lo decían las Siete Partidas ${ }^{45}$, esta regla no sólo se aplica a los actos que por antonomasia imponen la obligación de rendir una cuenta, como las guardas (art. 415 del $C C$ ), el mandato (art. 2155 del $C C$ ) o la agencia oficiosa (art. 2287 del CC) sino, también, a cualquier negocio jurídico por el que las partes dan por terminada y finiquitada una relación contractual, dándose por liberadas y declarando no adeudarse nada.

${ }^{40}$ Vial (n. 14), p. 184.

${ }^{41}$ Cfr. León Brailovsky, en Enciclopedia Jurídica Omeba, Buenos Aires, Bibliográfica Argentina, 1979, tomo 12, p. 288.

${ }^{42}$ Ricardo Villa-Real y Miguel Ángel del Arco Torres, Diccionario jurídico elemental, $2^{\mathrm{a}}$ ed., Granada, Editorial Comares, 2006, p. 180.

${ }^{43}$ Rodrigo Quijada S., Diccionario jurídico, Santiago, Editorial Jurídica Cono Sur, 1994, p. 271.

${ }^{44}$ Así Claro Solar (n. 8), t. 10, p. 289 y Ducci (n. 12), p. 280.

45 "Lo que se dize en esta ley e los mayordomos, e de los despenseros, entindese tambien de todos los otros omes, que tal pleyto, por promission fiziessen entre si, sobre cualquier fecho que sea semejante destos". Véase supra, punto 2. 
Como consecuencia de todo lo anterior, no cabe más que concluir:

a) La situación planteada en la primera parte del artículo 1465 del Código Civil, es un caso particular de objeto ilícito y

b) Esta primera parte del artículo, no sólo queda reducida a la rendición de una cuenta en la que media dolo, sino que se extiende a cualquier finiquito contractual que haya sido otorgado con dolo por una de las partes.

\section{Sentido y ALCANCE DEL ARTículo 1465 \\ DEl Código CIVIL}

Su sentido y alcance no es dudoso, ni en su primera ni en su segunda parte.

\section{A) La condonación del dolo futuro}

Acaso lo más evidente sea su segundo apartado del artículo 1465 del Código Civil, de acuerdo con el cual la condonación de dolo futuro no vale. Cualquier estipulación que de una $u$ otra forma tenga por objetivo restringir el grado de responsabilidad de una de las partes en una convención, reconoce como límite esta disposición legal. Los contratantes podrán estipular, por ejemplo, que en lugar de culpa levísima se responda de la leve o de la grave. De la misma forma podrán acordar que en lugar de la culpa leve se responda de la grave. Pero no podrán, anticipadamente, exonerar al deudor de la prestación de responder del dolo o de la culpa grave, dado que en materias civiles la culpa grave se equipara al dolo (art. 44 del $C C)^{46}$. El

${ }^{46}$ La culpa grave se opone a la buena fe y en materia civil este tipo de culpa es equivalente al dolo, pues "contiene una presunción de fraude, porque aquel que no hace lo que sabe que debe hacer, se reputa que obra con intención dolosa: magna culpa dolus est (Luis Claro Solar, Explicaciones de Derecho Civil chileno y comparado, reimpresión, Bogotá, Editorial Temis S.A. 1978, tomo 1, p. 151.

En este sentido señala Enrique Barros que es "un antiguo criterio distintivo en materia de convenciones exoneratorias de responsabilidad que sean válidas si tienen por objeto excusar la mera culpa, pero nulas si su objeto es condonar el dolo futuro o la culpa grave (artículos 1465, 1547 IV y 44 II). Aunque las disposiciones legales que sirven de fundamento a esta limitación se refieren a los incumplimientos contractuales, se puede tener por principio general de derecho que la condonación del dolo futuro es inexcusable”. Enrique Barros Bourie, Tratado de responsabilidad extracontractual, Santiago, Editorial Jurídica de Chile, 2007, p. 1.099 .

La asimilación del dolo a la culpa grave como una forma equivalente de imputabilidad, está presente a lo largo de casi todo el Código Civil. Así, por ejemplo, habrá derecho para quitar al padre o madre, o a ambos, la administración de los bienes del hijo, cuando se hayan hecho culpables de dolo, o de grave negligencia habitual (art. $257 \mathrm{del} C C$ ); contra el guardador que en su administración fuere convencido de dolo o culpa grave, habrá por parte del pupilo el derecho de apreciar y jurar la cuantía del perjuicio recibido (art. 423 del CC); puede ser 
tope a la convención sobre la limitación de responsabilidad en cuanto al grado de culpa es, por tanto, muy claro: no existe libertad para exonerar anticipadamente al deudor de dolo o culpa grave, y si aquello se hace, la disposición no vale por adolecer de objeto ilícito.

Un muy relevante fallo librado por la Corte Suprema con fecha 3 de julio de 2007, se hace cargo de esta precisa cuestión, restando valor de oficio a las cláusulas contractuales que de una u otra forma impongan la condonación del dolo o culpa grave futuros ${ }^{47}$.

Los hechos que sirven de base a este pronunciamiento son los siguientes:

removido de su cargo el albacea que haya actuado con culpa grave o dolo (art. 1300 del CC); la nulidad absoluta puede ser alegada por todo el que tenga interés en ello, excepto por quien celebró el acto o ejecutó el contrato sabiendo o debiendo saber el vicio que lo invalidaba (art. 1683 del $C$ C); cada cónyuge deberá, asimismo, recompensa a la sociedad por los perjuicios que le hubiere causado con dolo o culpa grave (art. 1748 del $C C$ ); en la sociedad conyugal las pérdidas o deterioros ocurridos en las especies o cuerpos ciertos de uno de los cónyuges deberá sufrirlos su dueño, salvo que se deban a dolo o culpa grave del otro cónyuge, en cuyo caso deberá éste resarcirlos (art. $1771 \mathrm{del} C C$ ); si por dolo o culpa grave del censuario pereciere o se hiciere infructífera la finca, será responsable de los perjuicios (art. 2035.3 del CC) y el agente oficioso que se ha hecho cargo de una cosa para salvarla de un peligro inminente, sólo es responsable del dolo o de la culpa grave (art. 2288.2 del CC).

Sobre el particular pueden verse las conclusiones de Cristián BANFI DEL Río, "La asimilación de la culpa grave al dolo en la responsabilidad contractual en Chile", en Revista Chilena de Derecho, vol. 27, N², Santiago, 2000, p. 291 y ss.

Obviamente que la asimilación de la culpa al dolo no es a nivel conceptual, sino que sólo respecto de los efectos civiles de uno y otro. Como escribe Arturo Alessandri: "que la culpa lata o grave equivale al dolo no quiere decir que jurídicamente sean una misma cosa porque eso sería hacer dos instituciones distintas, definidas en términos distintos en la ley, una sola y única cosa" (...) "que la culpa lata equivalga al dolo quiere decir única y exclusivamente que sus efectos jurídicos son los mismos, que las consecuencias jurídicas que resultan de haber culpa lata o grave y dolo por parte del deudor, son las mismas; o sea, que la responsabilidad del deudor es igual en caso de la culpa lata o en el caso del deudor que comete dolo". Arturo Alessandri Rodríguez, Teoría de las obligaciones, $2^{\mathrm{a}}$ ed., Santiago, Zamorano y Caperán, 1934, p. 75. Precisamente por eso, es que se ha resuelto que al decir la ley que la culpa grave o lata equivale al dolo, no ha hecho confusión alguna de ambos términos en el sentido de considerarlos sinónimos. Ello pugnaría abiertamente con el significado o acepción jurídica que a uno y otro corresponde. El precepto que establece dicha equivalencia se refiere lógica y naturalmente sólo a sus efectos civiles, o sea, a la igual responsabilidad que en lo civil debe afectar al que por su descuido o negligencia no emplea en la cosa sujeta a su administración el cuidado que aún las personas negligentes suelen emplear en sus negocios propios, que es lo que constituye culpa grave, y al que maliciosamente o con intención positiva infiere injuria a la persona o propiedad de otro, que es lo que por dolo se entiende. Revista de Derecho y Jurisprudencia vol. 19, N 1 , Santiago, 1922 , p. 415.

${ }^{47}$ Hermosilla Bonsái con Promotora CMR Falabella S. A., rol N 3901/2005. Número identificador Microjuris: MJJ10239. Número identificador Legal Publishing: 36584 
a) Una mujer celebró con CMR Falabella un contrato de línea de crédito o de apertura de crédito, en virtud del cual la primera se constituyó en la titular de una línea de crédito, para cuyo uso recibió de la segunda una tarjeta.

b) El uso de esta tarjeta quedó regido por un reglamento sobre uso de la tarjeta de crédito multirrotativo, que es parte integrante del contrato celebrado por las partes. Dicho reglamento indica que para poder hacer un pago en una cuenta CMR, es necesario señalar el número de RUT del titular, y el titular debe estampar su firma en un documento que acredite el otorgamiento del crédito. Además, en su cláusula 13 se establece que en caso de extravío, hurto o robo de la tarjeta, el usuario queda obligado a dar aviso de inmediato por escrito en las oficinas de la Sociedad Promotora CMR. Falabella S.A. y a efectuar la correspondiente denuncia ante Carabineros o Investigaciones de Chile. En dicha cláusula contractual se agrega, que hasta la fecha del aviso inclusive, o, en caso no darse éste, el usuario responderá de todas las utilizaciones o compras que se hagan con la tarjeta extraviada, hurtada o robada.

c) El día 21 de diciembre de 2002, un par de días antes que la titular diera aviso del hurto de su tarjeta, un tercero, utilizando la tarjeta de crédito en comento y la cédula de identidad que había previamente sustraído a su titular, adquirió en Falabella diversas cosas muebles y recibió en préstamo una cantidad de dinero.

d) La multitienda registró en la línea de crédito de la titular de la tarjeta como cargo el precio de aquellos bienes muebles y el monto del dinero objeto del mutuo indicado, y realizó las gestiones pertinentes para obtener su pago respecto de ella.

e) El uso de la tarjeta y de la cédula de identidad de la titular por parte de aquel tercero, lo fue sin la aquiescencia de su titular.

Ante esto, la titular de la tarjeta presentó, en lo principal, una demanda de nulidad absoluta de los cargos efectuados por la tienda comercial en la cuenta de la titular de la tarjeta de crédito por estimar que ellos adolecían de causa y objeto ilícitos; y en subsidio dedujo demanda tanto de nulidad relativa como de inoponibilidad de los cargos. Juntamente con estas acciones solicitó una indemnización de perjuicios por los daños patrimoniales y extrapatrimoniales derivados la actuación de la demandada.

La sentencia de primera instancia, dictada por el Tercer Juzgado Civil de Temuco con fecha 31 de diciembre de 2004, rechazó las demandas de nulidad absoluta y relativa, por no acreditarse la ilicitud del objeto o de la causa alegados; asimismo, rechazó la acción de inoponibilidad, argumentando que dicha sanción procede por la omisión de requisitos que no se relacionan con la validez de los actos jurídicos, como es el caso, en el que 
se alega la falta de consentimiento. Y, finalmente, respecto de la acción de indemnización de perjuicios deducida, sostuvo que no se acreditó que la demandada se encontrara obligada a efectuar la verificación de la identidad de la titular de la tarjeta de crédito -obligación que la actora indica incumplida negligentemente- que existiera un método de verificación diverso al de portar aquella tarjeta y la cédula de identidad, ni se estableció que quien practicó la identificación de la titular fuese la demandada o un dependiente de ella.

La Corte de Apelaciones de Temuco, en fallo de fecha 7 de julio de 2005, al pronunciarse sobre el recurso de apelación deducido en contra de la sentencia de primera instancia, la confirmó, argumentando para ello que la empresa CMR Falabella nada tendría que ver con la omisiones u operaciones de los funcionarios de las empresas Tienda Falabella y Banco Falabella, consistentes en no verificar la identidad de la titular al admitir su uso en la respectiva operación de compra de mercaderías y préstamo de dinero que sería el fundamento de la demanda, por lo que CMR Falabella, empresa diferente, no sería la legitimada pasiva de las acciones deducidas.

La Corte Suprema, acogió el recurso de casación en la forma interpuesto en contra de la sentencia de alzada, por entender que la sentencia de segundo grado fue extendida ultrapetita, toda vez que las motivaciones del fallo se apartaron completamente de las fundamentos esgrimidos por la apelante, rechazando la demanda sobre la base de un argumento diferente no alegado en el proceso, como lo era la falta de legitimación de la demandada.

En la sentencia de reemplazo la Corte Suprema acoge la demanda de nulidad absoluta de los cargos efectuados en la cuenta de la titular de la tarjeta de crédito. Para esto, de oficio, y con fundamento en el artículo 1465 del Código Civil, declara nula absolutamente la cláusula 13 del reglamento de uso de la tarjeta según la cual, y como se dijo, hasta la fecha del aviso del hurto, robo o pérdida de la tarjeta, el usuario es responsable de todas las utilizaciones o compras que se hagan con la tarjeta extraviada, hurtada o robada.

Sostiene la Corte Suprema, que esta estipulación es una especie de condonación de la culpa grave o dolo futuros, ya que el titular de la tarjeta asume la responsabilidad por actuaciones dolosas provenientes de terceros y de la negligencia inexcusable de los funcionarios de la tienda comercial que prescinden de verificar la identidad de la persona que hace el uso de la tarjeta que fue robada, hurtada o extraviada. Para este efecto, y tal como se viene diciendo, señala que, según el artículo 1465 del Código Civil, la condonación del dolo futuro no vale, 
"respecto de la cual se ha dicho que se trata de una disposición prohibitiva y, en consecuencia, su sanción es la nulidad absoluta, la sanción se produce por ser contraria a la buena fe que debe regir en materia contractual. Se agrega que en cuanto al dolo futuro, la estipulación de condonación sería generalmente genérica, pero la ley prohíbe tal estipulación en forma expresa, lo que acarrea la ilicitud del objeto y, consecuencialmente, la nulidad absoluta" (Avelino León Hurtado, El objeto de los actos jurídicos, Editorial Jurídica, páginas 58 y 59). (considerando. 17).

\section{Para la Corte:}

"la condonación del dolo futuro se encuentra tratada como una de las cláusulas más radicales de irresponsabilidad, denominándosele específicamente de garantía o responsabilidad del dolo, las cuales impone el contratante más fuerte al más débil por medio de contratos tipos unilaterales, estandarizados y por adhesión, ya que la persona que recibe la oferta solamente le corresponde suscribirlos en los términos que se le ofrecen al público en general, por prolongados espacios de tiempo y minuciosamente detallados o desistir de contratar. Estas cláusulas de garantía o responsabilidad, se les conoce en el derecho comparado como de seguro por particulares, cuya fuerza obligatoria ha sido cuestionada desde el siglo XIX, puesto que, como ocurre en el caso de autos, 'el futuro deudor se está haciendo cargo del dolo futuro, constituyéndose en una estipulación de responsabilidad por el hecho de terceros, en cuanto hagan uso indebido de la tarjeta de crédito; cláusula que también se establece en favor de terceros, quienes reciben dicha documentación, la validan y cursan la operación en el entendido que responderá de ella la persona que figura como titular de la tarjeta, relajándose la verificación de la identidad, por ello es que la doctrina las ha calificado como un verdadero seguro por particulares, caso en el cual se afirma , éste no debe ser gratuito para quien la establece y posibilita se garantice que no se le ocasionará ningún daño, puesto que, por regla general, a quien se pone a cubierto de responsabilidad es a empresas coligadas, por lo que se estima debe abonar una prima u otorgar una contraprestación equivalente, pues se está ante un contrato sinalagmático'. 'Se objeta esta estipulación de garantía o responsabilidad por particulares, tanto por la falta de causa de la obligación impide la plena eficacia de la cláusula y su analogía con el seguro no debe servir para convalidarla' (Planiol y Ripert, Tratado Práctico de Derecho Civil Francés, tomo vi, No 407, 
páginas 576 y 577), como, además, por el hecho que los seguros sólo los pueden otorgar las sociedades que reúnan los requisitos previstos por el legislador, aspecto que impediría a una persona natural acordar tal estipulación. Pero, no obstante que los citados tratadistas, otorgan cierta validez a la cláusula accesoria dirigida a garantizar la responsabilidad pecuniaria por los daños causados a terceros y por los cuales se hace cargo uno de los contratantes, agregan que, en todo caso, la promesa de garantizar a la otra parte contra las consecuencias de una causa criminal es nula, por su carácter ilícito, citando la decisión judicial que resuelve en tal sentido $^{48}$, con lo cual se excluyen las posibilidades de extender tal garantía a hechos ilícitos, salvo que provenga de un asegurador profesional ${ }^{49}$. En conclusión, 'resulta contrario a la norma del artículo 1465 del Código Civil, que dos partes convengan que una de ellas será responsable de las obligaciones que la otra le imponga, no obstante mediar culpa grave o dolo de ella o terceros, por cuanto importaría condonar esa culpabilidad en forma previa, lo que está prohibido. En efecto, esta condonación del dolo futuro se prohíbe tenga presencia en las relaciones contractuales, sin distinción, sea que éste dolo provenga de ellas o terceros, pero que se invoque por las partes en la convención, con mayor razón si éste hecho constituye un ilícito penal'. En este sentido, la cláusula $13^{\circ}$ del Reglamento sobre Uso de la Tarjeta de Crédito Multirrotativo CMR, establece que en caso de extravío, hurto o robo de la tarjeta, el usuario queda obligado a dar aviso de inmediato, por escrito, en las oficinas de la sociedad Promotora CMR Falabella S.A. y a efectuar la correspondiente denuncia ante Carabineros o Investigaciones de Chile, en lo cual y para resolver el presente caso, no se observan inconvenientes de validez. Sin embargo, no ocurre lo mismo, en cuanto, dicha cláusula contractual, agrega que hasta la fecha del aviso inclusive o, en caso de no darse éste, el usuario responderá de todas las utilizaciones o compras que se haga con la tarjeta hurtada o robada, puesto que con ello se estaría haciendo responsable de las consecuencias pecuniarias de un hecho ilícito, el que, además, expresamente se indica tiene connotaciones penales (...). En definitiva, y respecto de este último caso, 'el titular de la tarjeta de crédito se haría cargo del dolo futuro de un tercero, impetrado por una de las partes en la ejecución del contrato; se condonaría ese dolo futuro y permitiría que la contraria abone

${ }^{48}$ Req., octubre 25, 1909, D. 1911. 1. 433, S. 1913. 1. 273. Idem, No 408, p. 579.

${ }^{49} \mathrm{Idem}, \mathrm{N}^{\mathrm{O}} 407$, p. 578. 
a su línea de crédito toda cuenta o deuda que emane del uso de una tarjeta hurtada o robada. En este sentido, según se ha dicho, la norma del Código Civil, no circunscribe la condonación del dolo futuro a las partes, sino que una de ellas pretenda impetrarla en las relaciones que tienen lugar entre ambas con motivo de la ejecución de una convencióni’. Es así, que se está privilegiando dejar indemne a un tercero, quien no es parte en el contrato, puesto que no queda determinada con absoluta claridad la identidad del ofendido con el uso indebido de la tarjeta. En efecto, el administrador del sistema, en este caso Promotora CMR Falabella S. A., cursa el cobro y lo carga en la cuenta del titular de la tarjeta (...) en circunstancias que puede existir una serie de otros ilícitos como posibles suplantación de persona, falsificaciones, uso malicioso de instrumento privado mercantil o estafa respecto de personas que no son partes en el contrato, específicamente Tienda Falabella, de propiedad de la S. A. I. C. Falabella, empresa que aceptó el uso de la tarjeta sin constatar la correcta identificación de quien la utiliza, es más, dejando testimonio fílmico que no fue usada por la titular y respecto de quien, como lo anotara la demandada, no es parte en esta litis, sin que a su respecto pueda efectuarse alegación alguna por el actor" (considerando 18$)^{50}$.

Concluye en esta parte el fallo que:

“el artículo 1683 del Código Civil establece que la nulidad absoluta puede y debe ser declarada de oficio por el juez, aun sin petición de parte, cuando aparezca de manifiesto en el acto, atribución que ejercerá esta Corte, por lo palmario y evidente del vicio, declarando nula la mencionada cláusula que atribuye responsabilidad, esto es, en cuanto indica que hasta la fecha del aviso inclusive o, en caso de no darse éste, el usuario responderá de todas las utilizaciones o compras que se hagan con la tarjeta hurtada o robada, esto por adolecer de objeto ilícito en los términos del artículo 1465 del citado Código" (considerando 19).

En consecuencia, y como se explicaba al principio, cualquier estipulación contractual que de alguna manera persiga restringir el grado de responsabilidad de una de las partes en una convención, reconoce como límite lo prevenido en el artículo 1465 del Código Civil, en cuya virtud los contratantes no pueden exonerar al deudor de responder del dolo o de la

${ }^{50}$ Los destacados son del autor. 
culpa grave futuros, dado que en materias civiles la culpa grave se equipara al dolo.

\section{B) El finiquito obtenido con dolo}

En cuanto al primer apartado del artículo 1465 del Código Civil, la situación no es muy diversa de lo antes señalado. No vale el pacto de no pedir más en razón de una cuenta aprobada en cuanto al dolo contenido en ella, si no se ha condonado expresamente.

$\mathrm{El}$ precepto quiere decir que si se aprueba una cuenta o finiquito, no por ese hecho el que los aprobó queda impedido de reclamar lo que el obligado le deba, si es que ha existido dolo en la rendición de la cuenta o el otorgamiento del finiquito. Se trata de evitar que quien rinde la cuenta o extiende el finiquito se aproveche de su propio dolo. Ante el reclamo del perjudicado, se le impide escudarse en la aprobación de la cuenta o finiquito, por la sencilla razón de que, en su momento, el acto de rendición de cuenta u otorgamiento del finiquito resultó invalidado por el dolo que no fue expresamente condonado.

La aprobación de un finiquito contractual se entiende efectuado con base en la buena fe, por lo que quien lo extiende lo hace en la convicción 162 de que la cuenta que se le ha rendido es correcta y está exenta de fraude y de todo otro vicio. Por eso cuando el destinatario de la rendición o del finiquito los aprueba, no emite pronunciamiento alguno sobre el fraude que desconoce y no puede suponer; y si se estipula que no se pedirá más de lo que dice la rendición de la cuenta o se extiende un finiquito, ello no vale en cuanto al dolo que se contenga en la rendición de la cuenta o en el otorgamiento del finiquito. De esta forma, el perjudicado tiene la facultad de exigir el pago que se le deba o la indemnización que le corresponda y que con el fraude o dolo se intentó ocultar.

Esta conclusión la expone Luis Claro Solar con entera claridad: quien presta su aprobación de una cuenta lo hace en el entendido que las partidas que se le presentan son verdaderas;

"al aprobar la cuenta y otorgar finiquito de ella, no se ha pronunciado sobre el dolo que no conocía; y el pacto de no pedir más en razón de la cuenta aprobada no puede valer respecto del dolo contenido en la cuenta y que ignoraba el que la aprueba. Por consiguiente, si después de celebrado este pacto se descubre que la cuenta es dolosa, no podría rechazar el demandado la acción deducida en su contra, invocando ese finiquito y el pacto de no pedir más en razón de la cuenta" ${ }^{51}$.

${ }^{51}$ Claro Solar (n. 8), tomo 10, p. 289. 
En el mismo sentido se pronuncia Eugenio Velasco, quien expresa:

"al aprobar una persona las cuentas que otra debe rendirle, demuestra su conformidad con la rendición y queda obligada lógicamente a no exigir más por las cuentas; lo cual no obsta a que con posterioridad pueda iniciar las acciones correspondientes si ha descubierto la existencia de dolo, porque éste no pudo darse por condonado" ${ }^{52}$.

Todo lo anterior es muy razonable. Resulta natural que quien ha cometido el fraude no pueda aprovecharse de su propia e ilícita actuación, pues, como se ha explicado, es un principio general de derecho que a nadie le es lícito aprovecharse de su propia culpa o su propio dolo.

\section{CONDICIONES PARA LA CONDONACIÓN DEL DOLO PASADO}

La combinación de las dos reglas contenidas en el artículo 1465 del Código Civil, impone como conclusión inexcusable que el dolo solamente puede ser remitido cuando ya ha tenido lugar y siempre que ello se haga en forma expresa. No vale la condonación que se haga del dolo futuro; ni tampoco tiene valor un finiquito respecto del dolo contenido en él, si él no ha sido remitido de manera explícita y en el conocimiento de que ha tenido lugar ${ }^{53}$.

En este sentido la Corte Suprema, en el citado fallo de fecha 3 de julio de 2007, resolvió, con base en el artículo 1465 del Código Civil, "el perjudicado sólo puede condonar el dolo, o mejor dicho las consecuencias patrimoniales del mismo, con posterioridad, es decir, después que tal dolo ha existido y ha tomado conocimiento del mismo y los efectos que ha ocasionado" (considerando 17).

Los finiquitos de orden general no tienen valor respecto del dolo contenido en ellos, pues, como se ha dicho, quien lo otorga lo hace en la creencia de que quien rinde la cuenta o le propone el finiquito actúa de buena fe. Si con posterioridad a ello se descubre la existencia de dolo en la rendición de la cuenta o en el otorgamiento del finiquito, nada impide que el perjudicado reclame ante los tribunales lo que se le debe o los perjuicios que se le han causado.

Tanto es así, que se ha resuelto que la cuenta puede haber sido dada y aprobada judicialmente, y no por ello puede exonerarse quien la ha rendido de pagar lo que deba o de indemnizar los perjuicios, si ha existido dolo

\footnotetext{
${ }^{52}$ Velasco (n. 9), $\mathrm{N}^{\circ} 250$.

${ }^{53}$ Cfr. Larraín (n. 13), p. 310.
} 
de su parte en la rendición que ha efectuado. La Corte Suprema sentenció en su momento que:

"la relevación de rendir cuenta no exonera al mandatario de los cargos que contra él justifique el mandante, o sea, estos cargos pueden perseguirse con entera independencia de la rendición de cuentas; y contribuye a considerar, a su vez, que el juicio de rendición de cuentas no juzga más allá de las cuestiones propuestas, la circunstancia de que aún el pacto de no pedir más en razón de una cuenta aprobada, no impide instaurar acción por el dolo contenido en ella, lo que demuestra que, con mayor razón, una cuenta simplemente aprobada por la justicia, sin que medie pacto alguno, no es óbice para perseguir en juicio aparte, posteriormente, la culpa cometida en el cumplimiento del mandato" (considerando 15) ${ }^{54}$.

En consecuencia, para que pueda condonarse el dolo que incide en una rendición de cuenta o en un finiquito contractual, es necesario que la remisión cumpla con dos condiciones:

a) que ella sea expresa y

b) que se extienda en el cabal conocimiento de los hechos que constituyen el dolo. Si no es así, existe objeto ilícito en la aprobación de la cuenta o en la suscripción del finiquito.

\section{Conclusiones}

A manera de conclusión, bien puede afirmarse:

A) Las dos situaciones previstas en el artículo 1465 del Código Civil, son hipótesis específicas y calificadas de objeto ilícito y, por lo mismo, sancionables con nulidad absoluta del negocio en que inciden en la forma que lo ordena el artículo 1682 del Código Civil. De modo que existe objeto ilícito tanto en el pacto de no pedir más en razón de una cuenta aprobada respecto del dolo contenido en ella como en la condonación del dolo futuro.

B) El objeto ilícito al que se refiere la primera parte del artículo $1465 \mathrm{del}$ Código Civil, no queda reducido a la sola rendición de una cuenta, sino que se extiende a todo finiquito contractual que contenga el mismo vicio.

C) Si se aprueba una cuenta o se otorga un finiquito en los que ha existido dolo, no por ello quien ha aprobado la cuenta u otorgado

${ }^{54}$ Revista de Derecho y Jurisprudencia vol. 34, No 1, Santiago, 1937, p. 277. 
el finiquito queda impedido de reclamar a su contraparte lo que ella le deba o los perjuicios causados. La ley impide que quien rinde la cuenta o recibe el finiquito se beneficie de su propia malicia, en la medida que, ante la demanda del perjudicado, se excluye la excepción de aprobación de la cuenta o de suscripción de finiquito, ya que ellos son inválidos por el objeto ilícito que contienen.

D) Para que pudiere entenderse condonado el dolo en un finiquito o en la aprobación de una cuenta, es necesario que haya sido remitido expresamente y en perfecto conocimiento de que ha tenido lugar. Si no fuere así, existe objeto ilícito en el otorgamiento del finiquito o en el pacto de no pedir más.

E) La nulidad absoluta por cualquiera de los objetos ilícitos del artículo 1465 del Código Civil, puede alegarse por todo el que tenga interés en ello, excepto por el que ha ejecutado el acto o celebrado el contrato, sabiendo o debiendo saber el vicio que lo invalidaba; no puede sanearse por la ratificación de las partes, ni tampoco por un lapso de tiempo inferior a diez años.

\section{BibLIOGRAFÍA}

Alessandri Besa, Arturo, La nulidady la rescisión en el Derecho Civil chileno, Santiago, Imprenta Universitaria, 1949, tomo 1.

Alessandri Rodríguez, Arturo, Teoría de las obligaciones, $2^{\text {a }}$ ed., Santiago, Zamorano y Caperán, 1934.

Alessandri Rodríguez, Arturo, Manuel Somarriva Undurraga y Antonio VoDanovic Haclicka, Tratado de Derecho Civil, Santiago, Editorial Jurídica de Chile, 1998, tomo II.

BANFi DEL Río, Cristián, "La asimilación de la culpa grave al dolo en la responsabilidad contractual en Chile", en Revista Chilena de Derecho, vol. 27, N 2 , Santiago, 2000.

Barcia Lehemann, Rodrigo, Lecciones de Derecho Civil chileno, Santiago, Editorial, Jurídica de Chile, 2007, tomo i: Del acto jurídico.

Brailovsky, León, en Enciclopedia Jurídica Omeba, Buenos Aires, Bibliográfica Argentina, 1979, tomo 12.

Barros Bourie, Enrique, Tratado de responsabilidad extracontractual, Santiago, Editorial Jurídica de Chile, 2007.

Claro Solar, Luis, Explicaciones de Derecho Civil chileno y comparado, reimpresión, Bogotá, Editorial Temis S.A. 1978, tomo 1.

Claro Solar, Luis, Explicaciones de Derecho Civil chileno y comparado, reimpresión, Bogotá, Editorial Temis S.A., 1979, tomo 10. 
Domínguez Águila, Ramón, Teoría general del negocio jurídico, Santiago, Editorial Jurídica de Chile, 1977.

Ducci Claro, Carlos, Derecho Civil. Parte general, $4^{\mathrm{a}}$ ed., Santiago, Editorial Jurídica de Chile, 1995.

Elizalde, Miguel, Concordancias de los artículos del Código Civil Chileno entre sí con los artículos del Código Francés, Santiago, Imprenta de La Libertad, 1871.

García del Corral, Justiniano (traductor y compilador), Cuerpo de Derecho Civil Romano, Barcelona, Editorial Lex Nova 1889, tomo 1: Instituta - Digesto.

Guzmán Brito, Alejandro, Andrés Bello codificador. Historia de la fijación y codificación del derecho civil en Chile, Santiago, Ediciones de la Universidad de Chile, 1982, tomo 1.

Guzmán Brito, Alejandro, Código Civil chileno, Navarra, Aranzadi, 2006.

Larraín Ríos, Hernán, Lecciones de Derecho Civil, Santiago, Editorial Jurídica de Chile, 1994.

León Hurtado, Avelino, El objeto de los actos jurídicos, $2^{\mathrm{a}}$ ed., Santiago, Editorial Jurídica de Chile, 1983.

López Santa María, Jorge, Los contratos. Parte general, $4^{\mathrm{a}}$ ed., Santiago, Editorial Juridica de Chile, 2005.

Quijada S., Rodrigo, Diccionario jurídico, Santiago, Editorial Jurídica Cono Sur, 1994.

Repertorio de legislación y jurisprudencia chilenas. Código Civil y leyes complementarias, Santiago, Editorial Jurídica de Chile, 1997, tomo IV.

Velasco Letelier, Eugenio, El objeto ante la jurisprudencia, memoria, Santiago, Universidad de Chile, Facultad de Ciencias Jurídicas y Sociales, 1941, N² 250. Disponible en www.cybertesis.cl

Vial del Río, Víctor, Teoría general del acto jurídico, Santiago, Editorial Jurídica de Chile 2006.

Villa-Real, Ricardo y Miguel Ángel del Arco Torres, Diccionario jurídico elemental, $2^{\mathrm{a}}$ ed., Granada, Editorial Comares, 2006. 